\title{
HAJLÉKONY GOLYÓSCSAPÁGY VIZSGÁLATA
}

\author{
Németh Géza, Dr. Péter Józs ef
}

\begin{abstract}
The main difference between the epicyclic gear drives and the harmonic drives is the existance of a toothed wheel with high flexibility in the latter one. The flexible wheel of the harmonic drive derived from the epicyclic gear drive with one planet gear is mainly the wheel with external teeth and named as flexspline. Its flexibility is assured by the shell-like shape. The task of the wave generator is the creation of waves. The wave generator makes connection between the flexspline and the solid ring with internal teeth called circular spline. The number of teeth of circular spline is greater than that of the flexspline, and the difference is usually two. Among the numerous solutions of wave generators the mechanically operated ones are in general use, especially the design containing a thin raced ball bearing fitted onto an elliptical plug. Is serves as a high efficiency torque converter. This special bearing is not cotained by the bearing catalogues. Its design is in relation with the common deep groove ball bearing. This paper try to show the results of research work on this special bearing.
\end{abstract}

\section{A hullámhajtómü hatásfokát befolyásoló tényezők}

Hullámhajtómű hatásfokát leginkább két tényező befolyásolja. Az egyik a fogazati kapcsolódás, a másik pedig a hullámgenerátor. Természetesen a kedvező müködés elengedhetetlen feltétele az, hogy a hullámkerék és gyürűkerék fogazata jól kapcsolódjon egymással és ezt természetesen ezt a generátor alakja is erősen befolyásolja (1. ábra) [9].

A hatásfokjavítás igazi lehetőségei azonban a hullámgenerátorban rejlenek. Általában kis teljesítmények átviteléről lévén szó, nem az energiamegtakarítás oldaláról jelentkezik a hatásfok javításának igénye. Azonban az élettartam jelentősen javulhat egy lágy, jó hatásfokú generátor beépítésével. Csökkenthető a hajtó oldal tehetetlenségi nyomatéka, kiegyensúlyozatlansága, kisebb lesz a melegedés és a kopások.

\section{A csapágy elemeinek alakváltozása}

A kis tömeg és jó hatásfok kettős követelményének leginkább a bütykös generátor, ezek közül is a hajlékony csapágyas típus felel meg. A hajlékony csapágy külső és belső gyürüi is közel azonos keresztmetszetüek, és ha a gyürü szelvényét összehasonlítjuk egy hasonló külső átmérőjü mélyhornyú golyóscsapágyéval, a különbség szembetünő (2.ábra). 

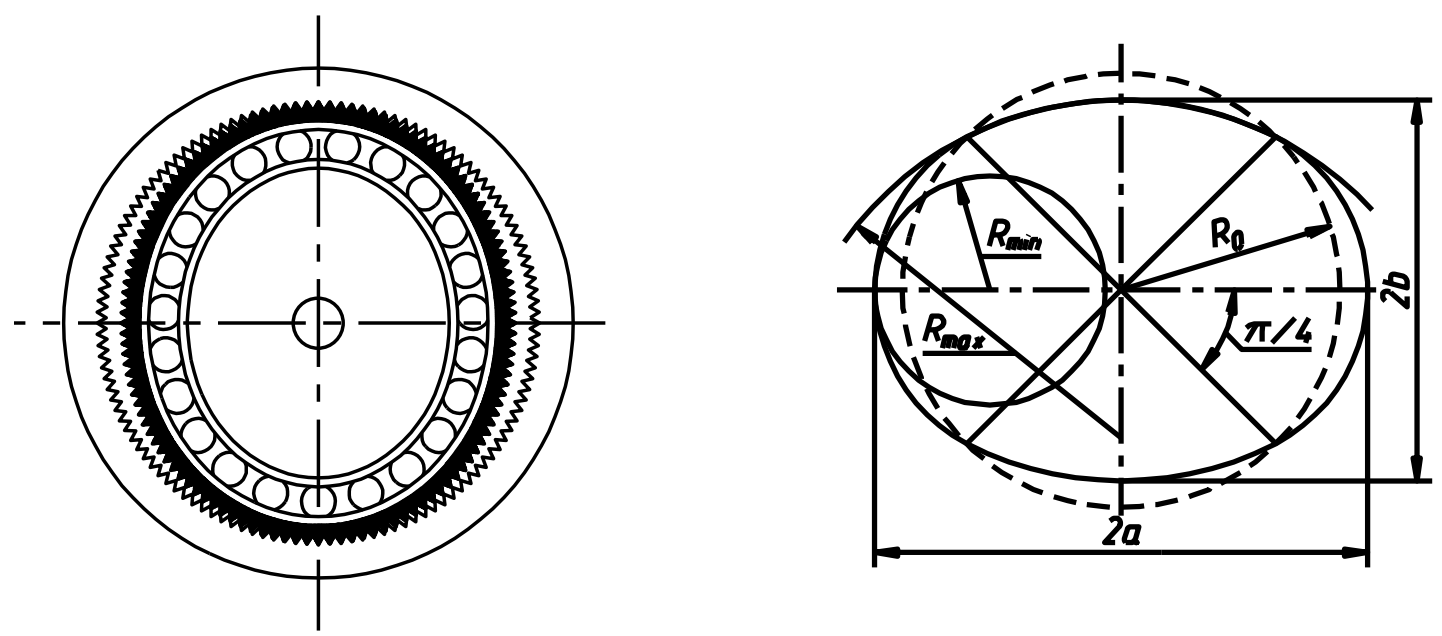

1. ábra A külsö fogazatú hullámkerék, a gyürükerék valamint a hajlékony golyóscsapágy és az $R_{0}+w_{0} \cos (2 \phi)$ függvénnyel leirt bütyök szerelési egysége
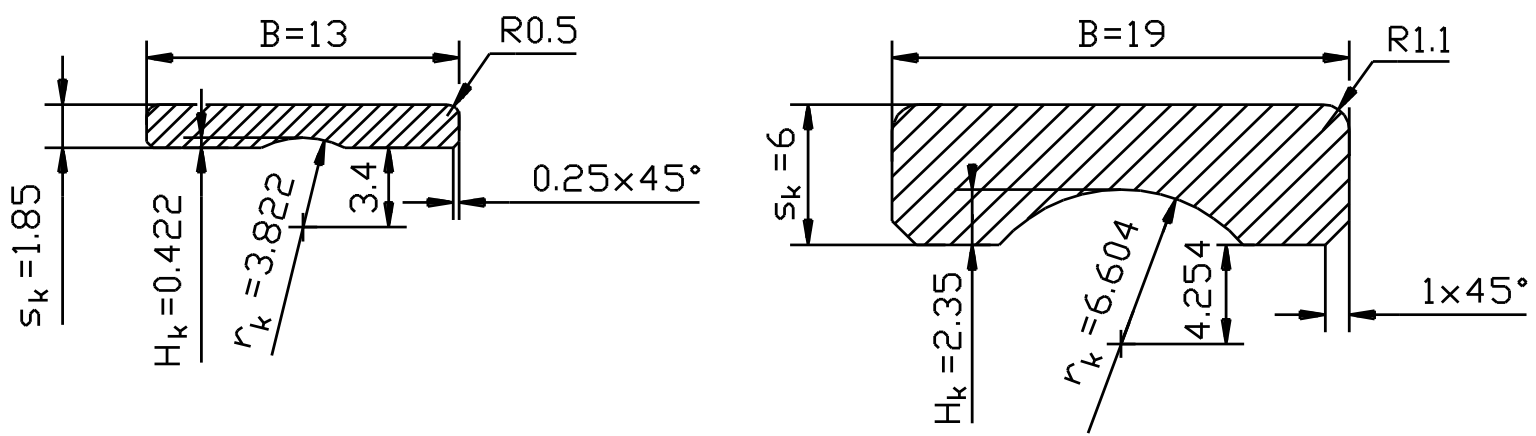

2. ábra A mélyhornyú és a hajlékony golyóscsapágy külső gyürüinek keresztmetszete

A csapágy vizsgálatát a fogazati kapcsolódás szempontjából kedvező bütyökprofil típusának kiválasztásával kezdjük. A fogazat határozza meg a deformációs hullám nagyságát is, tehát a korábbi munkákban [8,9] tárgyalt bütyökprofilok nagy és kistengelyének viszonyát. A hajlékony csapágy belső gyürüjének kezdeti, szereléskor előálló igénybevételét alapvetően ez a viszonyszám, továbbá a a bütyökprofil görbületváltozásának mértéke határozza meg. A szerelési hézagról a $\mathrm{H} / \mathrm{h}$ jellegü illeszkedés tájékoztat. Szemlélet alapján következtethetünk a belső gyürü és bütyök érintkezési tartományára. Vonatkoztassunk el attól, hogy a csapágy a két gyürüvel, a kosárral és a golyókkal egyetlen szerelési egységet alkot. Ez egyébként sem túlságosan nehéz feladat, hiszen a mủanyag kosár könnyen kiemelhető, a golyók rendezettségének megszüntetésével valóban sérülésmentesen szétszedhető a csapágy. Ha a különálló belső gyürủt húzzuk a bütyökre, a profil nagytengelyének környezetében az érintkezés biztosan létrejön, a kistengelynél viszont biztosan nem. Végeselemes analízis kimutatta, hogy a belső gyürü a bütykön csak a nagytengely menti $\sim 110-110^{\circ}$-os szögtartományban fekszik fel [8]. A többi részen hézaggal illeszkedik. A bütyök profilja egy körre szuperponált $\mathrm{w}_{0} \cos (2 \phi)$ függvény (3. ábra) szerint változott. A gyártási alak- és helyzethibáktól eltelkintettünk. 

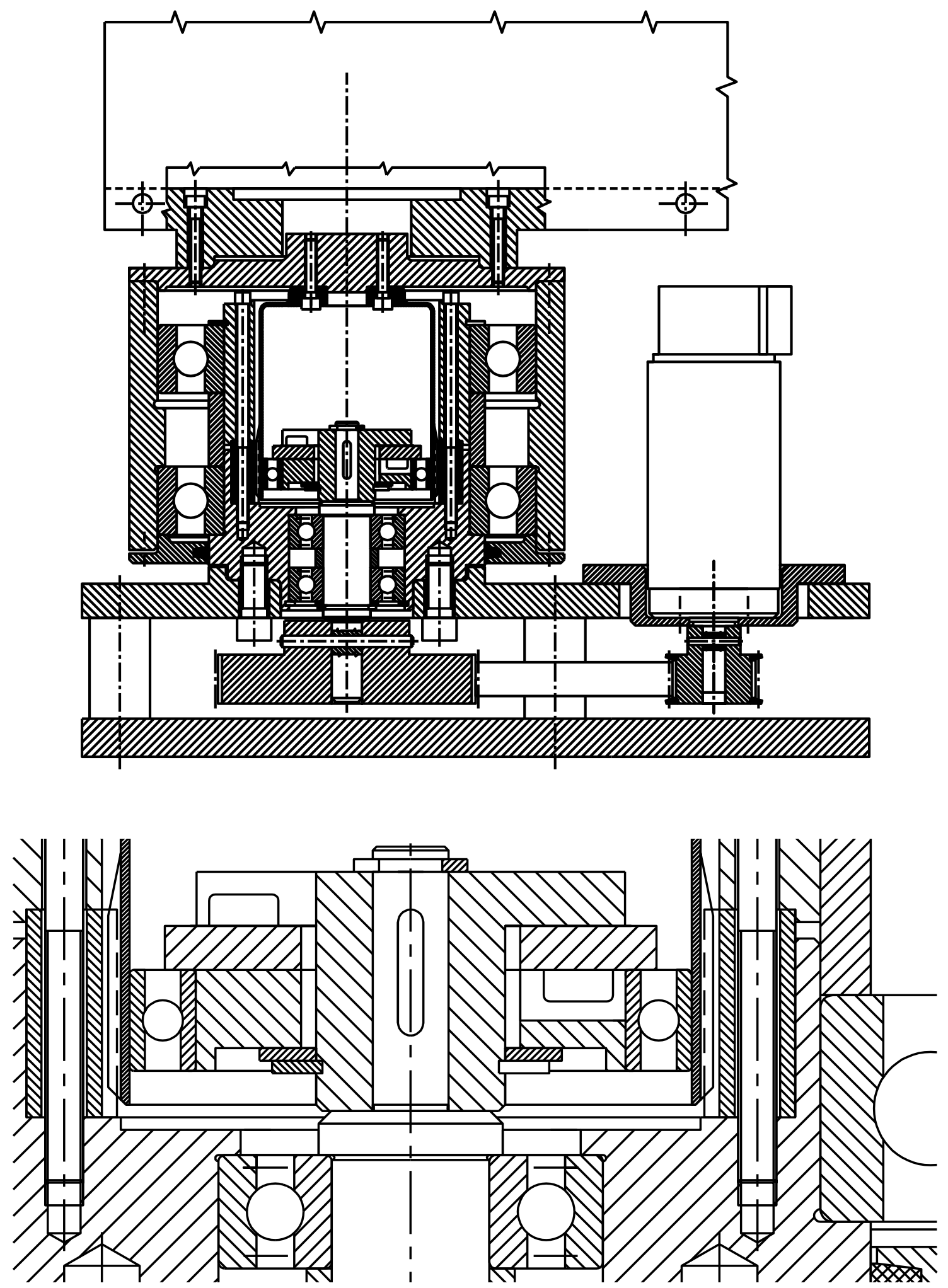

3. ábra Robotkar hajtása hullámhajtómüvel. A generátor radiális kiegyenlitő tengelykapcsolón keresztül kapja hajtását

Mivel a gyürük vékonyak, a golyók hornyai is sekélyek. A nagyszámú gördülőelem a bütyökprofil pontos átszármaztatását hivatott megvalósítani. A külső gyürü és golyó behelyezése nem módosítja számottevően a belső gyürü korábbi alakját. A külső gyürü viszont egy sokszög alakot vesz fel. A hullámkerék H/h jellegű illesztésével, továbbá az így előállt szerelési egységnek a merev gyürükerékbe 
történő helyezésével kialakul az elemek egy lehetséges alakváltozás-állapota. És végül az üresjárat és a terhelés ezt az állapotot változtatja át jelentős mértékben. A hullámkerék eredeti elliptikus alakja erősen torzul. Ráadásul egy pohár alakú hullámkerék alkotóinak szögelfordulása kikényszerítheti a külső csapágygyürü alkotóinak a szögelfodulását. És végül nem szabad megfeledkezni a csapágyhézag hatásáról sem.

A két kapcsolódási tartomány (1.ábra) meghatározza a hullámgenerátor radiális helyzetét, ezért meg kell teremteni szabad beállásának lehetőségét. Ezt a feltételt a 3. ábra hajtómúve teljesíti.

A programot a Művelődési és Közoktatási Minisztérium Felsőoktatási Programfinanszírozási Pályázata támogatta.

\section{Irodalom}

[1] M. ten Bosch, Gépelemek, Kossuth Nyomda, Budapest, 1964, 808p.

[2] Kozák I., KIMHER programrendszer héjak, lemezek és tárcsák forgásszimmetrikus feladataira, síkbeli tartókra (programismertető és felhasználói leírás), Miskolci Egyetem, 1994, 106p.

[3] COSMOS/M Geostar User Guide (Version 1.65A),Structural Research and Analysis Corporation, Santa Monica, California, 1992.

[4] Molnár L. \& Varga L., Gördülőcsapágyak tervezése, Müszaki Könyvkiadó, Budapest, 1977, 452p.

[5] Volkov, D.P. \& A.F.Krajnev, Hullámhajtóművek, Műszaki Könyvkiadó, Budapest, 1984, p209-214.

[6] Péter J., Fogaskerék-hullámhajtómủ és tengelykapcsoló kapcsolódásának vizsgálata, A Tudományos Minősítő Bizottsághoz benyújtott és elfogadott kandidátusi értekezés, Miskolc, 1992, 111p.

[7] Németh G. \& Péter J.,Egy különleges csapágy néhány jellemzője, Géptervezők és termékfejlesztők X. Országos Szemináriuma kiadványkötete,Miskolc,pp251-255,1995.

[8] Németh G. \& Péter J., Az egysorú mélyhornyú golyóscsapágy és a hajlékony golyóscsapágy különbségei, microCAD '96 Nemzetközi számítástechnikai Tudományos Konferencia , Gép- és szerkezettervezés (J/1 Szekció) kiadványkötete, Miskolc-Egyetemváros, pp21-25, 1996.

[9] Németh G. \& Péter J., A bütyök és a hajlékony golyóscsapágy kapcsolata, Fiatal Műszakiak Tudományos Ülésszaka kiadványa, II. kötet, pp101-104, Kolozsvár, 1997.

Németh Géza, egyetemi tanársegéd,

Dr. Péter József, Ph.D., a müszaki tudomány kandidátusa, egyetemi docens

Miskolci Egyetem Gépelemek Tanszéke, Miskolc-Egyetemváros H-3515, Hungary,Telffax: +36 46327643 


\title{
Investigation of Flexible Ball Bearing
}

\begin{abstract}
G. Németh J. Péter, Ph.D.
The main difference between the epicyclic gear drives and the harmonic drives is the existance of a toothed wheel with high flexibility in the latter one. The flexible wheel of the harmonic drive derived from the epicyclic gear drive with one planet gear is mainly the wheel with external teeth and named as flexspline. Its flexibility is assured by the shelllike shape. The task of the wave generator is the creation of waves. The wave generator makes connection between the flexspline and the solid ring with internal teeth called circular spline. The number of teeth of circular spline is greater than that of the flexspline, and the difference is usually two. Among the numerous solutions of wave generators the mechanically operated ones are in general use, especially the design containing a thin raced ball bearing fitted onto an elliptical plug. Is serves as a high efficiency torque converter. This special bearing is not cotained by the bearing catalogues. Its design is in relation with the common deep groove ball bearing. This paper try to show the results of research work on this special bearing.
\end{abstract}

\section{Hajlékony golyóscsapágy vizsgálata}

A nagy kinematikai áttétel megvalósítására alkalmas hullámhajtóművek leginkább abban térnek el a hagyományos bolygóművektől, hogy alapelemeik közül legalább egy kifejezetten hajlékony. Az egy bolygókerekes, belső kapcsolódású bolygóműből származtatható fogaskerekes hullámhajtómüben ez a hajlékony alapelem legtöbbször a külső fogazatú kerék, amelyet hullámkeréknek nevezünk. Az elnevezés a müködés során rajta periodikusan áthaladó hullámokból adódik. Hajlékonyságát héjszerủ kialakítása biztosítja. A hullámok létrehozása a hullámgenerátor feladata. Ez hozza kapcsolatba a hullámkereket az általában kettővel nagyobb fogszámú, belső fogazatú merev gyürükerékkel. A számos megoldás közül a mechanikus elven müködők, ezen belül a bütykösek terjedtek el. A bütyök és a hullámkerék közé a veszteségek csökkentése érdekében hajlékony golyóscsapágyat helyeznek. Ez a csapágytípus a csapágygyárak termékválasztékában nem szerepel. Leginkább az egysorú mélyhornyú golyóscsapágyra hasonlít. Jelen dolgozatban a szerzők e különleges csapágyra vonatkozó vizsgálatuk néhány eredményét kívánják bemutatni.

Géza NÉMETH, assistant lecturer

József PÉTER, Ph.D., associate professor

University of Miskolc, Deptartment of Machine Elements, Miskolc-Egyetemváros H-3515, Tel/fax: +3646327643 